\title{
STUDIES ON THE HUMAN IMMUNOGLOBULIN ALLOTYPES IN FIVE POPULATIONS IN THE USSR
}

\author{
Hideo Matsumoto, ${ }^{1}$ Tokiko Miyazaki, ${ }^{1}$ Yuri, G. Rychkov, ${ }^{2}$ \\ Olga V. Zhukova, ${ }^{2}$ Irina A. LeBedeVA, ${ }^{2}$ V.M. KONDIK, ${ }^{2}$ \\ I.G. Udina, ${ }^{2}$ V.A. SPITZIN, ${ }^{2}$ J. BATSUUR, ${ }^{2}$ Y.V. ShNADER, ${ }^{2}$ \\ Kimiyoshi TsujI, ${ }^{3}$ Takashi TAKahashI, ${ }^{3}$ and Yoshinobu NAKaO ${ }^{4}$ \\ ${ }^{1}$ Department of Legal Medicine, Osaka Medical College, Takatsuki, \\ Osaka 569, Japan \\ ${ }^{2}$ Laboratory of Human Genetics, Institute of General Genetics, \\ USSR Academy of Sciences, Moskow, USSR \\ ${ }^{3}$ Department of Transplantation, Tokai University School of Medicine, \\ Boseidai, Kanagawa 259-11, Japan \\ ${ }^{4}$ Department of Medicine, Kobe University School of Medicine, \\ Kobe, Hyogo 650, Japan
}

\begin{abstract}
Summary Serum samples obtained from a total of 664 individuals representing five populations (Koryaks, Northern Buriats, Southern Buriats, Mongols and Uralians) in the USSR were tested for $\operatorname{Glm}(\mathrm{a}, \mathrm{z}, \mathrm{x}$ and $\mathrm{f})$ and $\mathrm{G} 3 \mathrm{~m}(\mathrm{~b} 0, \mathrm{bl}, \mathrm{b} 3, \mathrm{~b} 4, \mathrm{~b} 5, \mathrm{~s}, \mathrm{t}, \mathrm{g}$ and $\mathrm{u}$ ), and $\mathrm{Km}(1)$ allotypes. According to $\mathrm{Gm}$ patterns, the first four of these populations are characterized by the presence of four haplotypes, namely Gm a,z;g,u, Gm a,z,x;g,u, Gm a,z;b0,b3, $\mathrm{b} 5, \mathrm{~s}, \mathrm{t}$ and $\mathrm{Gm} \mathrm{a}, \mathrm{f} ; \mathrm{b} 0, \mathrm{~b} 1, \mathrm{~b} 3, \mathrm{~b} 4, \mathrm{~b} 5, \mathrm{u}$ which are characteristic of Mongoloid populations, whereas the Uralian population is characterized by three haplotypes, Gm a,z;g,u, Gm a,z,x;g,u, and $\mathrm{Gm}$ f;b0,b1,b3,b4,b5,u which are common to Caucasoids as well as the $\mathrm{Gm}$ a,z;b0,b3,b5,s,t haplotype typical of northern Mongoloid populations. Results obtained from the four Mongoloid populations in Siberia indicate clear genocline, extending from Kamchatka to Mongol in which the haplotype frequency of $\mathrm{Gm}$ $\mathrm{a}, \mathrm{z} ; \mathrm{g}, \mathrm{u}$ changes from 0.714 to 0.431 and that of the $\mathrm{Gm}$ a,f; $\mathrm{b0}, \mathrm{b} 1, \mathrm{~b} 3, \mathrm{~b} 4, \mathrm{~b} 5, \mathrm{u}$ haplotype from 0.031 to 0.231 . On the other hand, the $\mathrm{Gm}$ a,z;b0,b3,b5,s,t haplotype is found in the highest incidence $(0.307)$ among Buriats from north Baikal, a population considered to have the most prominent Mongoloid characters, and indicates a cline from the Baikal to east and to south. In contrast to the $\mathrm{Gm}$ system, no significant regional differences in the frequencies of the $\mathrm{Km}^{1}$ allele were observed among these different populations.
\end{abstract}




\section{INTRODUCTION}

Inherited structural differences in human immunoglobulins are referred to as allotypes, genetic markers or allotypic markers. So far, genetic markers have been found for the IgG heavy $(\mathrm{H})$ chain ( $\mathrm{Gm}$ markers), the IgA H chain (Am markers), the IgE H chain (Em marker) recently described by van Loghem et al. (1984), and the kappa type light $(\mathrm{L})$ chain (Km markers, formerly called Inv) common to all classes of immunoglobulin.

The first allotype of the $\mathrm{H}$ chain of human immunoglobulin was detected in 1956 by Grubb and Laurell. Since then more than 20 allotypes have been described that occur on the $\mathrm{H}$ chains of three of the four IgG subclasses, (IgG1, $\mathrm{IgG} 2$, and $\mathrm{IgG} 3$ ). The $\mathrm{Gm}$ system provides genetic markers which are unique in studies of human genetics, particularly in the characterization of different populations and in studies of genetic drift and gene flow determined by the presence of either a unique haplotype in a particular race or by differences in the frequencies of the same haplotypes in a given ethnic group.

This study of Siberian populations in the USSR forms part of an extensive survey aimed at investigating the distribution of $\mathrm{Gm}$ and $\mathrm{Km}$ alleles among Mongoloid populations from Southeast Asia through East Asia into South America and results from a collaboration between Japanese and Soviet scientists, and was supported by the Soviet Academy of Sciences in September 1983. Here we report the distributions of $\mathrm{Gm}$ and $\mathrm{Km}$ allotypes and haplotypes in five distinct populations from Ural and Siberia in the Soviet Union.

\section{MATERIALS AND METHODS}

Serum samples from a total of 664 unrelated individuals from five distinct populations in the USSR (65 Koryaks from Kamchatka, 137 from Buriats in north Baikal, Buratskaja, ASSR, 81 from Buriats in south Baikal, Buratskaja, ASSR, 64 from Mongols in Mongolia, ASSR and 317 from Uralian group, Ural, USSR) were tested for $\mathrm{Glm}(\mathrm{a}, \mathrm{z}, \mathrm{x}$ and $\mathrm{f}), \mathrm{G} 3 \mathrm{~m}(\mathrm{b0}, \mathrm{bl}, \mathrm{b3}, \mathrm{b} 4, \mathrm{~b} 5, \mathrm{~s}, \mathrm{t}, \mathrm{g}, \mathrm{u}$ and $\mathrm{c} 3$ ), and $\mathrm{Km}(\mathrm{l})$ allotypes. The reagents used for these tests as well as the numerical and alphabetical nomenclature used are presented in Table 1. The tests were carried out using previously described methods (Matsumoto and Takatsuki, 1968).

\section{RESULTS AND DISCUSSION}

Data of $\mathrm{Gm}$ phenotypes in five distinct Soviet populations are presented in Table 2, and estimated frequencies of Gm haplotypes are presented in Table 3. Haplotype frequencies and degree of fit with the Hardy-Weinberg distribution were determined using the computer program MAXIM (Kurczynski and Steinberg, 1967).

Of the Gm markers tested, only GIm(a,z,x,f) and G3m(b0,b1,b3,b4,b5,s,t,g,u) 
Table 1. Human gammaglobulin allotypes $(\mathrm{Gm}$ and $\mathrm{Km})$ used in these studies.

\begin{tabular}{|c|c|c|c|c|}
\hline \multicolumn{3}{|c|}{ Nomenclature (W.H.O.) } & \multirow{2}{*}{ Anti-allotype } & \multirow{2}{*}{ Anti- $\mathrm{Rh}_{0}$} \\
\hline Alphabeti & ical a & Numerical & & \\
\hline \multirow[t]{4}{*}{ Gim } & $\mathrm{a}$ & 1 & 3552 & 2880 \\
\hline & $x$ & 2 & 2984 & 2880 \\
\hline & f & 3 & 2871 & 3097 \\
\hline & $z$ & 17 & 3272 & 2880 \\
\hline \multirow[t]{10}{*}{ G3m } & $b^{1}$ & 5 & 7514 & 3656 \\
\hline & $b^{0}$ & 11 & 0058 & 3656 \\
\hline & $b^{3}$ & 13 & 4721 & 3656 \\
\hline & $b^{4}$ & 14 & 0663 & 3656 \\
\hline & $b^{5}$ & 10 & 1340 & 3656 \\
\hline & $\mathrm{g}$ & 21 & 1642 & 3359 \\
\hline & s & 15 & 2624 & 3068 \\
\hline & $\mathrm{t}$ & 16 & 0197 & 3068 \\
\hline & $\mathrm{u}$ & 26 & 1369 & 2127 \\
\hline & $c^{3}$ & 5 & 2781 & 2646 \\
\hline $\mathrm{Km}$ & 1 & 1 & 5872 & 2447 \\
\hline
\end{tabular}

a Alphabetical nomenclature is used in this paper.

Table 2. Gm phenotype frequencies among five Soviet populations.

\begin{tabular}{|c|c|c|c|c|c|c|c|c|c|c|}
\hline \multirow{2}{*}{ Phenotype } & \multicolumn{2}{|c|}{$\begin{array}{c}\text { Koryaks } \\
\text { (Kamchatka) }\end{array}$} & \multicolumn{2}{|c|}{$\begin{array}{c}\text { Buriats } \\
\text { (North Baikal) }\end{array}$} & \multicolumn{2}{|c|}{$\begin{array}{c}\text { Buriats } \\
\text { (South Baikal) }\end{array}$} & \multicolumn{2}{|c|}{$\begin{array}{c}\text { Mongols } \\
\text { (Mongolia, ASSR) }\end{array}$} & \multicolumn{2}{|c|}{$\begin{array}{c}\text { Uralian } \\
\text { (Ural, USSR) }\end{array}$} \\
\hline & Obs. & Exp. & Obs. & Exp. & Obs. & Exp. & Obs. & Exp. & Obs. & Exp. \\
\hline$a, z, g, u$ & 33 & 33.2 & 30 & 30.7 & 20 & 19.6 & 13 & 11.3 & 30 & 24.5 \\
\hline$a, z, b^{0}, b^{3}, b^{5}, s, t, g, u$ & 22 & 18.6 & 41 & 39.7 & 18 & 21.7 & 9 & 12.1 & 2 & 5.0 \\
\hline$a, z, x, g, u$ & 4 & 5.3 & 23 & 24.6 & 11 & 11.2 & 4 & 6.0 & 14 & 17.3 \\
\hline $\begin{array}{l}a, z, f, b^{0}, b^{1}, b^{3}, b^{4}, b^{5}, \\
g, u\end{array}$ & 1 & 2.9 & 9 & 7.6 & 12 & 8.9 & 14 & 12.5 & 102 & 107.0 \\
\hline$a, z, x, b^{0}, b^{3}, b^{5}, s, t, g, u$ & 0 & 1.4 & 14 & 13.6 & 6 & 5.5 & 3 & 2.9 & 3 & 1.5 \\
\hline $\begin{array}{l}a, z, f, b^{0}, b^{1}, b^{3}, b^{4}, b^{5}, \\
\quad s, t, u\end{array}$ & 0 & 0.8 & 3 & 4.9 & 4 & 4.9 & 8 & 6.7 & 13 & 10.9 \\
\hline$a, z, b^{0}, b^{3}, b^{5}, s, t$ & 2 & 2.6 & 13 & 12.9 & 8 & 6.0 & 4 & 3.2 & 0 & 0.3 \\
\hline $\begin{array}{l}a, z, x, f, b^{0}, b^{1}, b^{3}, b^{4}, b^{5}, \\
\quad g, u\end{array}$ & 3 & 0.2 & 4 & 2.6 & 2 & 2.2 & 5 & 3.0 & 35 & 32.7 \\
\hline$a, f, b^{0}, b^{1}, b^{3}, b^{4}, b^{5}, u$ & 0 & 0.1 & 0 & 0.5 & 0 & 1.0 & 1 & 3.4 & 0 & 0.0 \\
\hline $\mathrm{f}, \mathrm{b}^{\mathrm{0}}, \mathrm{b}^{\mathbf{1}}, \mathrm{b}^{\mathbf{3}}, \mathrm{b}^{4}, \mathrm{~b}^{5}, \mathrm{u}$ & 0 & 0.0 & 0 & 0.0 & 0 & 0.0 & 0 & 0.0 & 117 & 116.7 \\
\hline Total & 65 & 65.0 & 137 & 137.0 & 81 & 81.0 & 61 & 61.0 & 316 & 316.0 \\
\hline
\end{tabular}


Table 3. Gm haplotype frequencies among five Soviet populations.

\begin{tabular}{|c|c|c|c|c|c|c|c|c|c|c|}
\hline \multirow{2}{*}{ Gm haplotype } & \multicolumn{2}{|c|}{$\begin{array}{c}\text { Koryaks } \\
\text { (Kamchatka) }\end{array}$} & \multicolumn{2}{|c|}{$\begin{array}{c}\text { Buriats } \\
\text { (North Baikal) }\end{array}$} & \multicolumn{2}{|c|}{$\begin{array}{c}\text { Buriats } \\
\text { (South Baikal) }\end{array}$} & \multicolumn{2}{|c|}{$\begin{array}{c}\text { Mongols } \\
\text { (Mongolia, ASSR) }\end{array}$} & \multicolumn{2}{|c|}{$\begin{array}{c}\text { Uralian } \\
\text { (Ural, USSR) }\end{array}$} \\
\hline & Freq. & SE & Freq. & SE & Freq. & SE & Freq. & $\mathrm{SE}$ & Freq. & SE \\
\hline$a, z ; g, u$ & .714 & .039 & .473 & .030 & .492 & .039 & .431 & .045 & .279 & .018 \\
\hline$a, z, x ; g, u$ & .055 & .020 & .162 & .022 & .125 & .026 & .102 & .027 & .085 & .011 \\
\hline$a, z ; b^{0}, b^{3}, b^{5}, s, t$ & .200 & .035 & .307 & .028 & .272 & .035 & .230 & .038 & .029 & .006 \\
\hline $\begin{array}{c}a, f ; b^{0}, b^{1}, b^{3}, b^{4}, \\
b^{5}, u\end{array}$ & .031 & .015 & .058 & .014 & .111 & .025 & .238 & .038 & .000 & .000 \\
\hline$f ; b^{0}, b^{1}, b^{3}, b^{4}, b^{5}, u$ & .000 & .000 & .000 & .000 & .000 & .000 & .000 & .000 & .608 & .019 \\
\hline$\chi^{2}$ & \multicolumn{2}{|c|}{7.132} & \multicolumn{2}{|c|}{1.469} & \multicolumn{2}{|c|}{3.663} & \multicolumn{2}{|c|}{5.493} & \multicolumn{2}{|c|}{5.842} \\
\hline d.f. & \multicolumn{2}{|c|}{4} & \multicolumn{2}{|c|}{4} & \multicolumn{2}{|c|}{5} & \multicolumn{2}{|c|}{5} & \multicolumn{2}{|c|}{4} \\
\hline$P$ a & \multicolumn{2}{|c|}{0.102} & \multicolumn{2}{|c|}{0.832} & \multicolumn{2}{|c|}{0.598} & \multicolumn{2}{|c|}{0.357} & \multicolumn{2}{|c|}{0.211} \\
\hline
\end{tabular}

a $P$ for goodness of fit to Hardy-Weinberg distribution based on haplotype frequencies shown. SE, standard error.

were found and all samples were negative for $\mathrm{G} 3 \mathrm{~m}(\mathrm{c} 3)$ as would be predicted. Among the four Siberian populations (Koryaks from Kamchtka, Buriats in north Baikal, Buriats in south Baikal and Mongols in Mongolia), nine phenotypes were observed which are explained by the presence of four haplotypes (Gm a,z;g,u, Gm $\mathrm{a}, \mathrm{z}, \mathrm{x} ; \mathrm{g}, \mathrm{u}, \mathrm{Gm} \mathrm{a}, \mathrm{z} ; \mathrm{b} 0, \mathrm{b3}, \mathrm{b} 5, \mathrm{s,t}$ and $\mathrm{Gm} \mathrm{a}, \mathrm{f} ; \mathrm{b0}, \mathrm{bl}, \mathrm{b3}, \mathrm{b4}, \mathrm{b5}, \mathrm{u})$ characteristic of Mongoloid populations. On the other hand, 8 phenotypes determined by the presence of three haplotypes, (Gm a,z;g,u, Gm a,z,x;g,u, and Gm f;b0,b1,b3,b4,b5,u) characteristic of Caucasoids, in addition to the $\mathrm{Gm}$ a,z; $\mathrm{b0}, \mathrm{b} 3, \mathrm{~b} 5, \mathrm{~s}, \mathrm{t}$ haplotype which occurs in northern Mongoloids (Matsumoto, 1977; Matsumoto et al., 1982) were observed in the Uralian group. Agreement was obtained for all five populations between the observed and the expected frequencies on the basis of the Hardy-Weinberg equilibrium of phenotypes.

To determine if significant heterogeneity in haplotypic distributions exists among the four Siberian populations, haplotype frequencies were analysed using a contingency chi-square test according to the methods of Snedecor (Snedecor, 1956). A test for heterogeneity of each of four haplotypes in the four populations are given in Table 4. Homogeneity was found between Buriats from northern Baikal and southern Baikal $\left(\chi_{3}{ }^{2}=5.79, p=0.12\right)$, except for the haplotype $\mathrm{Gm}$ $\mathrm{a}, \mathrm{f} ; \mathrm{b} 0, \mathrm{~b} 1, \mathrm{~b} 3, \mathrm{~b} 4, \mathrm{~b} 5, \mathrm{u}\left(\chi_{1}{ }^{2}=3.94\right.$; significant at the $5 \%$ level $)$. The results show most highly significant heterogeneity between Koryaks and Mongols $\left(\chi_{3}{ }^{2}=46.63, p=\right.$ $0.000)$, notably for the $\mathrm{Gm} \mathrm{a,z;g,u}$ haplotype $\left(\chi_{1}{ }^{2}=20.69, \mathrm{p}=0.000\right)$ and for the $\mathrm{Gm}$ a,f;b0,b1,b3,b4,b5,u haplotype $\left(\chi_{1}{ }^{2}=23.68, \mathrm{p}=0.000\right)$. Heterogeneity can also be seen between Koryaks and Buriats from both southern and northern Baikal $\left(\chi_{3}{ }^{2}=27.56, p=0.000\right.$; and $\chi_{3}{ }^{2}=36.26, p=0.000$, respectively), particularly with re- 
Table 4. Heterogeneity in $\mathrm{Gm}$ haplotypic distributions among four Siberian populations.

\begin{tabular}{|c|c|c|c|c|}
\hline & & $\begin{array}{c}\text { Buriats } \\
\text { (South Baikal) }\end{array}$ & $\begin{array}{c}\text { Buriats } \\
\text { (North Baikal) }\end{array}$ & $\begin{array}{c}\text { Koryaks } \\
\text { (Kamchatka) }\end{array}$ \\
\hline \multirow{5}{*}{$\begin{array}{c}\text { Buriats } \\
\text { (N.BaikaI) }\end{array}$} & ag & $x_{(1)}^{2}=0.151, p=0.697$ & & $x_{(I)}^{2}=20.715, p=0.000$ \\
\hline & $\operatorname{axg}$ & $x_{(1)}^{2}=1.102, p=0.294$ & & $x_{(I)}^{2}=9.059, p=0.002$ \\
\hline & $a b^{3} s t$ & $x_{(1)}^{2}=0.600, p=0.438$ & & $x_{(I)}^{2}=5.054, p=0.024$ \\
\hline & $a f b^{1} b^{3}$ & $x_{(1)}^{2}=3.935, p=0.047$ & & $x_{(I)}^{2}=1.430, p=0.231$ \\
\hline & Total & $x_{(3)}^{2}=5.788, p=0.122$ & & $x_{(3)}^{2}=36.258, p=0.000$ \\
\hline \multirow{5}{*}{$\begin{array}{c}\text { Buriats } \\
\text { (S.Baikal) }\end{array}$} & $\mathrm{ag}$ & & & $x_{(1)}^{2}=14.692, p=0.000$ \\
\hline & $\operatorname{axg}$ & & & $x_{(1)}^{2}=4.751, p=0.041$ \\
\hline & $a b^{3} s t$ & & & $x_{(1)}^{2}=2.029, p=0.754$ \\
\hline & $a f b^{1} b^{3}$ & & & $x_{(1)}^{2}=6.683, p=0.009$ \\
\hline & Total & & & $x_{(3)}^{2}=27.555, p=0.000$ \\
\hline \multirow{5}{*}{$\begin{array}{l}\text { Mongols } \\
\text { (Mongolia) }\end{array}$} & ag & $x_{(1)}^{2}=1.054, p=0.384$ & $x_{(1)}^{2}=0.604, p=0.437$ & $x_{(1)}^{2}=20.694, p=0.000$ \\
\hline & $\operatorname{axg}$ & $x_{(I)}^{2}=0.365, p=0.545$ & $x_{(1)}^{2}=2.480, p=0.175$ & $x_{(1)}^{2}=1.928, p=0.765$ \\
\hline & $a b^{3} s t$ & $x_{(1)}^{2}=0.652, p=0.419$ & $x_{(1)}^{2}=2.471, p=0.116$ & $x_{(I)}^{2}=0.325, p=0.568$ \\
\hline & $a f b^{1} b^{3}$ & $x_{(1)}^{2}=8.076, p=0.004$ & $x_{(1)}^{2}=26.946, p=0.000$ & $x_{(1)}^{2}=23.682, p=0.000$ \\
\hline & Total & $x_{(3)}^{2}=10.146, p=0.017$ & $x_{(3)}^{2}=32.502, p=0.000$ & $x_{(3)}^{2}=46.629, p=0.000$ \\
\hline
\end{tabular}

$a g=a, z ; g, u, \quad a x g=a, z, x ; g, u, a b^{3} s t=a, z ; b^{0}, b^{3}, b^{5}, s, t$ and $a f b^{1} b^{3}=a, f ; b^{0}, b^{1}, b^{3}, b^{4}, b^{3}, u$.

spect to the Gm a,z;g, u haplotype $\left(\gamma_{1}^{2}=14.69, p=0.000 ;\right.$ and $\chi_{1}{ }^{2}=20.72, p=0.000$, respectively), and also between Mongols and Buriats from northern Baikal $\left(\chi_{3}{ }^{2}=\right.$ $32.50, \mathrm{p}=0.000)$, notably for the $\mathrm{Gm}$ a,f; $\mathrm{b} 0, \mathrm{~b} 1, \mathrm{~b} 3, \mathrm{~b} 4, \mathrm{~b} 5$, $\mathrm{u}$ haplotype $\left(\chi_{1}{ }^{2}=26.95\right.$, $\mathrm{p}=0.000$ ). The results of these significant differences observed among haplotype frequencies between the four Siberian populations confirm the anthropological observations which would indicate considerable local genetic differences among them. In general, however, the Gm patterns of the four Siberian populations are characterized by a high frequency of the Gm a,z;g,u haplotype and a very low frequency of the $\mathrm{Gm}$ a, $\mathrm{f} ; \mathrm{b} 0, \mathrm{~b} 1, \mathrm{~b} 3, \mathrm{~b} 4, \mathrm{~b} 5, \mathrm{u}$ haplotype, which is similar to that observed previously in northern Mongoloids (Matsumoto, et al., 1982). Furthermore, as seen in the Table 3, there is a regular increase from south to north in the frequency of the $\mathrm{Gm} a, z ; g, \mathrm{u}$ haplotype and a regular decrease in the frequency of the $\mathrm{Gm} a, f$; $\mathrm{b} 0, \mathrm{~b} 1, \mathrm{~b} 3, \mathrm{~b} 4, \mathrm{~b} 5, \mathrm{u}$ haplotype. In contrast to these results, the $\mathrm{Gm} \mathrm{a}, \mathrm{z} ; \mathrm{b} 0, \mathrm{~b} 3, \mathrm{~b} 5, \mathrm{s,t}$ haplotype was observed in the highest incidence in Buriats from northern Baikal but decreases in a gentle cline both to the north and south of this population.

On the other hand, the Uralian population is considered to be Caucasoid in origin based on a high incidence of the $\mathrm{Gm} \mathrm{f} ; \mathrm{b} 0, \mathrm{~b} 1, \mathrm{~b} 3, \mathrm{~b} 4, \mathrm{~b} 5, \mathrm{u}$ haplotype, but is 
Table 5. Km phenotype and allele frequencies among five Soviet populations.

\begin{tabular}{|c|c|c|c|c|}
\hline \multirow{2}{*}{ Population } & \multirow{2}{*}{ No. Tested } & \multirow{2}{*}{$\mathrm{Km}(1)$} & \multicolumn{2}{|c|}{$K m^{1}$} \\
\hline & & & Frequency & SE \\
\hline Koryaks (Kamchatka) & 65 & 16 & 0.13 & 0.03 \\
\hline Buriats (North Baikal) & 137 & 9 & 0.03 & 0.01 \\
\hline Buriats (South Baikal) & 81 & 17 & 0.11 & 0.02 \\
\hline Mongols (Mongolia, ASSR) & 61 & 8 & 0.07 & 0.02 \\
\hline Uralian & 316 & 46 & 0.08 & 0.01 \\
\hline
\end{tabular}

SE, standard error.

admixed with Mongoloids in a relatively high proportion. Considering the Uralian

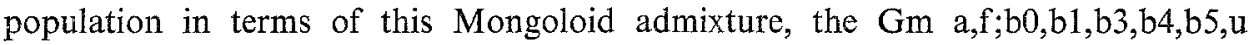
haplotype which is considered to be a southern gene defining Mongoloid populations, was not found. The Gm a,z;b0,b3,b5,s,t haplotype, which is a marker of northern Mongoloid populations, was, however, observed at a relatively high frequency. Therefore, the Uralian population is basically Caucasoid in origin but with considerably high Mongoloid admixture.

The $\mathrm{Km}$ data is shown in Table 5. The $\mathrm{Km}^{1}$ allele frequency was estimated by the square root of the $\mathrm{Km}(1-)$. In contrast to the significant variation observed in $\mathrm{Gm}$ haplotypes, the $\mathrm{Km}$ data does not reveal any significant variation among the five Soviet populations studied.

Four sera (3 from Mongols and 1 from Uralian) excluded from a total of 664 serum samples tested, possessed uncommon phenotypes which could not be explained by the presence of the four commonly occurring $\mathrm{Gm}$ haplotypes. From all sera tested, two unusual phenotypes were encountered. In Mongols, the Gm $\mathrm{a}, \mathrm{z}, \mathrm{f}, \mathrm{b} 0, \mathrm{~b} 1, \mathrm{~b} 3, \mathrm{~b} 4, \mathrm{~b} 5, \mathrm{~s}, \mathrm{t}, \mathrm{g}, \mathrm{u}$ type, which is identical to the variant described in Chinese and Koreans by Schanfield et al. (1972a, 1972b) was observed on three occasions. In the Uralian group, the $\mathrm{Gm}(\mathrm{a}, \mathrm{z}, \mathrm{x}, \mathrm{b0}, \mathrm{b} 1, \mathrm{~b} 3, \mathrm{~b} 4, \mathrm{~b} 5, \mathrm{~g}, \mathrm{u})$ variant identical to that reported by Schanfield et al. $(1972 \mathrm{a}, 1972 \mathrm{~b})$ was found in one individual. It was not possible to define the unusual $\mathrm{Gm}$ haplotype which contributed to the genesis of these phenotypes, because family data were not available.

This study was supported by the Soviet Academy of Sciences and the Japanese Cultural Association with Foreign Countries.

\section{REFERENCES}

Cavalli-Sforza, L.L. 1966. Population structure and human evolution. Proc. Roy. Soc. (London), B164: 362-379.

Grubb, R. and Laurell, A.B. 1956. Hereditary serological human serum groups. Acta Pathol. Microbiol. Scand. 39: 390-398. 
Kurczynski, T.W. and Steinberg, A.G. 1967. A general program for maximum likelihood estimation of gene frequencies. Am. J. Hum. Genet. 19: 178-179.

Loghem, E. van. 1971. The formal genetics of the immunoglobulin systems. Ann. N.Y. Acad. Sci. 190: 136-149.

Matsumoto, H. and Takatsuki, K. 1958. Gm factors in Japan: Population and family studies. $J_{p n n .}$ J. Human Genet. 13: 10-19.

Matsumoto, H. 1977. Application of the Gm system to population genetics and anthropology. J. Anthropol. Soc. Nippon 85: 265-280.

Matsumoto, H., Miyazaki, T., Ishida, N., and Katayama, K. 1982. Mongoloid populations from the viewpoints of Gm patterns. Jpn. J. Human Genet. 27: 271-282.

Nei, M. 1972. Genetic distance between populations. Am. Natur. 106: 283-292.

Nei, M. 1975. Molecular Population Genetics and Evolution, North-Holland, Amsterdam and New York, pp. 197-202.

Schanfield, M.S., Gershowitz, H., Ohkura, K., and Blackwell, R.Q. 1972a. Studies on the immunoglobulin allotypes of Asiatic populations. II. Gm and Inv allotypes in Chinese. Hum. Hered. 22: 138-143.

Schanfield, M.S., Gershowitz, H., Hong, Kyon-Ja, and Shim, Bong-Sop. 1972b. Studies on the immunoglobulin allotypes of Asiatic populations. III. Gm and Inv allotypes among random Koreans. Hum. Hered. 22: 144-148.

Snedecor, C.W. 1956. Statistical Methods. 5th ed. Ames. Jowa State Univ. Press.

W.H.O. 1976. Review of the notation for the allotypic and related markers of human immunoglobulins. W.H.O. meeting on human immunoglobulin allotypic markers. J. Immunogenet. 3: $357-362$. 